\title{
Supporting Innovation Through a Mechanism of Accelerated Depreciation in the Republic of Uzbekistan
}

\author{
Francisco Jesús Ferreiro Seoane \\ University of Santiago de Compostela, A Coruña, Spain \\ Manuel Octavio Del Campo Villares \\ University of A Coruña, A Coruña, Spain \\ Khaydarov Ravshan Rahmonovich \\ Dublin Institute of Technology, Dublin, Ireland \\ Zaynalov Jahongir Rasulovich \\ Samarkand Institute of Economics and Services, Samarkand, Republic of Uzbekistan
}

\begin{abstract}
The state plays a paramount role in the development of the national economy. In this development process, the state with direct levers, using the available tools as state financial support, banks systems, and tax policy, can provide incentives to identify areas for managing business entities. Obviously, one of the main levers of the state policy is a tax policy. Tax policy plays a crucial role in supporting innovation activities, which in turn provide sustainable economic growth for both the economic entities and the state. Whereas, due to guaranty of sustainable production line in the market economy, the economic entity always needs additional financial resources that ensure the renewal of fixed assets. The present paper focuses on the variation of calculations of the depreciation fund in the Republic of Uzbekistan. Regarding to both the tax rates and interval of the residual value of fixed assets, without attracting financial flows, the economic entities can update fixed assets, which on the same time increases the tax payments to the state budget in case of Uzbekistan.
\end{abstract}

Keywords: tax, depreciation fund, variation, fixed assets, business entities, Uzbekistan

\section{Introduction}

The state plays a paramount role in the development of the national economy. Using the available tools, the state can provide incentives to identify areas for managing business entities in their own areas (Stradi \& Haven, 2005). Apart from being used for fiscal purposes, the tax system can be used to stimulate investment in the real sector of a transition economy (Arkin, Slastnikov, \& Arkina, 2003). To this end, one of the essential

Francisco Jesús Ferreiro Seoane, Ph.D., professor, Department of Applied Economics, University of Santiago de Compostela, A Coruña, Spain.

Manuel Octavio Del Campo Villares, Ph.D., professor, Department of Applied Economics, University of A Coruña, A Coruña, Spain.

Khaydarov Ravshan Rahmonovich, Ph.D., researcher, College of Business, Department of Accounting and Finance, Dublin Institute of Technology, Ireland.

Zaynalov Jahongir Rasulovich, Ph.D., professor, Department of Finance and Insurance services, Samarkand Institute of Economics and Services, Samarkand, Republic of Uzbekistan.

Correspondence concerning this article should be addressed to Francisco Jesús Ferreiro Seoane, Paseo de los Puentes No.12 4 A. 15004 A Coruña, Spain. Telephone number: 0034629881 909. E-mail: franciscojesus.ferreiro@usc.es. 
elements of the tax system is depreciation. It does not transfer the cost of assets to the costs of the merchandise (Kurczodyna, 2010). Depending on the proper choice of incentives and business management, the outcome will affect the growth of productivity of fixed assets and also increase job creation, which is a fundamental factor for the development of the national economy.

Generally, only economic factors influence the process of the formation of a depreciation fund, accruing depreciation using different types of acceleration factors (Stradi \& Haven, 2005; Joppe, Sproge, \& Zelgalvis, 2010). The state only allows a sinking fund to redistribute in time the amount of depreciation that affects the tax base for income and property taxes. As a result, the entity will still pay the amount due of said taxes. As it is possible to see, the state is inert to the process of renewal and the increase of fixed assets, which directly affect the increase of a company's revenue and consequently an increase in payments for income tax and property taxes. Indeed, the growth of fixed assets (BPA) in industry significantly increases the growth of GDP and tax revenue by expanding production capacity.

In due time, the West came up with a form of investment such as leasing, introducing an acceleration factor, and this has led to a situation in which, to date, most investment is precisely this form of financing (Filip, 2012). In time, Western countries were not afraid to cut the tax base for income tax and property tax. As shown in the present long-term practice, leasing is constantly and rapidly evolving, and no state is going to give up this form of investment in basic production assets, as the growth of BPA for any state produces only positive effects.

Furthermore, in most cases, the economic entity benefits from leasing, as a depreciation fund dramatically increases when it is used. The economic entity does not always invest in BPA. Unfortunately, nowadays such a revolutionary mechanism has been created that any entity would be persuaded to constantly increase the quality and quantity of their BPA, stimulating it with such a tool, therefore they would not have the desire to spend dramatically, thus increasing the depreciation fund for secondary targets.

With such a mechanism which influences the process of forming the source of BPA updates, actions must be committed both by the economic entity and the state (Arkin \& Slastnikov, 2007). On one hand, the entity must enforce a depreciation policy that takes into account market conditions and is aimed at establishing a depreciation fund. On the other hand, the state must provide a well-defined tax policy in order to encourage the business entity towards a constant resource flow to the depreciation fund, which ensures BPA renewal (Hall, 2005).

This joint mechanism would allow the business entity to reasonably form and share a depreciation fund, based on the market situation, not on a desire to dramatically reduce payable taxes. Such a fund could provide reasonably increasing amounts of tax revenue for the state, secured by an increase in production, which is the effect of previous investments in BPA, and also adjust the behavior of the economic entity in so far as the allocation of the depreciation fund.

\section{Experience of Developed Countries}

Over the last decade, the successful industrial development and commercialization of scientific results have been one of the key goals of European economic policy (Joppe et al., 2010). In many countries of the world, albeit to a varying extent, there are tax benefits associated with depreciation write-offs. They are used to stimulate the development of specific industries, the promotion of R\&D activities and for general investment recovery.

In Germany, the methods and rates of depreciation are the subject of an elaborate legislation. The Federal 
Ministry of Finance and the Ministry of Finance formally approved tables (more than 90), which define the methods and rates of depreciation for different types of assets. Linear coefficients were initially used. Therefore, for industrial buildings and structures, the permitted annual rate of depreciation write-off is $4 \%$ (which means taking their service life to over 25 years), industrial machinery and equipment is $10 \%$ (lifetime of 10 years), computers is $20 \%$, and road transport is $20-25 \%$, etc.. But at the same time, German law gives companies the right to use accelerated depreciation on these assets. The most widely used method for admission, compared to the straight-line method of depreciation, is drastically overestimating during the first years of life of fixed assets and dramatically underestimating for subsequent years (for a fixed term of the proposed general services). Thus, for industrial buildings and structures the annual depreciation rate shall be $10 \%$ for the first four years of service, $5 \%$ for the following three years, and $2.5 \%$ for the next 18 years. For production machinery and equipment, annual depreciation rates can be tripled in the first few years of their service life (Lobont, Moldovan, \& Corduneanu, 2010; Hall, 2005).

In the U.S., tax incentives which were introduced in the 60 s and 70 s during a period of high inflation, underwent significant changes in the more stable economic environment of the 80s. Adopted in 1986, the law on state tax policy became more focused, although it narrowed the application of the previously authorized tax benefits (Kurczodyna, 2010). Depreciation periods were increased, but mostly only with respect to the passive part of fixed assets (buildings and structures); nevertheless, the active part of their depreciation was accelerated even more, so that with a five year write-off period, it was possible to write off up to $64 \%$ of the cost of equipment during the first two years.

The systems of depreciation write-offs in Sweden allow equipment to have a service life of up to three years and may be expensed in the year of acquisition, and the entire cost of machinery and equipment within four to five years. In France, it is possible to use accelerated depreciation for equipment used in the manufacturing and process industries, energy-saving and environment sectors, information equipment, etc., for example, a computer can absorb up to one year. The coefficient of accelerated depreciation on equipment lifetimes of up to four years is 1.5 , a service life of five to six years is 2, and more than six years is 2 to 2.5 .

Accelerated depreciation methods are used not only in developed countries, but also in developing countries to varying degrees. It is common for these methods to be used intensively in order to stimulate investment in technical renewal.

In Russia, the following factors are allowed with respect to accelerated depreciation: For fixed assets, operating in harsh environments and/or multiple shifts is up to 2; assets used in agricultural production and in small businesses is 2, and up to 3 for leased objects (Shatalova, 2012). Along with the use of accelerated depreciation, small businesses can write off a further depreciation of up to $50 \%$ of the original cost of fixed assets with a service life of more than three years (Arkin \& Slastnikov, 2007).

Similarly, in the Ukraine, the use of accelerated depreciation is allowed for small businesses during the first year of operation and a further writes off depreciation of up to $20 \%$ of the original value of fixed assets with a service life greater than three years.

\section{Use of Accelerated Depreciation in Uzbekistan}

In the Republic of Uzbekistan, in recent years, there have been significant reforms regarding taxation. The constant reduction of the tax burden in relation to GDP, from $28.5 \%$ in 2000 to $21.3 \%$ (excluding earmarked extra-budgetary funds) in 2012, contributed to many of the objectives of the anti-crisis program (Karimov, 
2013). Currently, out of 177 countries for which tax burden data is available, Uzbekistan ranked 91. The tax burden in Denmark, Sweden, Belgium, and France exceeds the level of $40 \%$ of GDP.

In the territory of the Republic of Uzbekistan, there are taxes and other obligatory payments in accordance with those updated in 2008 by the tax code. Recently, fiscal levers have been gradually introduced to encourage a transitional development of innovation in the economy. The given privileges, of course, contribute to innovation activities in various sectors of the economy. In recent years, there has been a steady trend towards lower rates of taxes and fees, which is shown in Table 1 (Republic of Uzbekistan, 2009).

Table1

Dynamics of Tax Payments Rates for Legal Entities in the Republic of Uzbekistan

\begin{tabular}{lllllllllll}
\hline$N$ & Type of tax payments & 2000 & 2005 & 2006 & 2007 & 2008 & 2009 & 2010 & 2011 & 2012 \\
\hline 1 & Income tax & 31 & 15 & 12 & 10 & 10 & 10 & 9 & 9 & 9 \\
2 & VAT & 20 & 20 & 20 & 20 & 20 & 20 & 20 & 20 & 20 \\
3 & Property tax of legal entities & 4 & 3.5 & 3.5 & 3.5 & 3.5 & 3.5 & 3.5 & 3.5 & 3.5 \\
4 & Single tax & $\sim$ & 12 & 13 & 10 & 8 & 8 & 7 & 6 & 5 \\
5 & Income tax for the improving and & 8 & 8 & 8 & 8 & 8 & 8 & 8 & 8 & 8 \\
& dev of s. Infr. & & & & & & \\
6 & Compulsory payments to R.R.F & 1.5 & 1.5 & 1.5 & 1.5 & 1.5 & 1.5 & 1.5 & 1.4 & 1.4 \\
7 & Mandatory payments to the P.F. & 0.7 & 0.7 & 0.7 & 0.7 & 1 & 1 & 1.5 & 1.6 & 1.6 \\
8 & Single social payment & 40 & 31 & 24 & 25 & 24 & 24 & 25 & 25 & 25 \\
9 & Tax on dividends individuals & $\sim$ & 15 & 10 & 10 & 10 & 10 & 10 & 10 & 10 \\
\hline
\end{tabular}

Source: Compiled by author.

The table shows that for the period from 2000 to 2012, the income tax rate was reduced from $31 \%$ to $9 \%$, property tax from $4 \%$ to $3.5 \%$, and social security payment from $40 \%$ to $25 \%$. Other taxes and mandatory contributions paid by legal entities have not changed. The corporate tax rate for small businesses has been reduced from $12 \%$ in 2005 to $5 \%$ in 2012 .

The types of taxes and fees are characterized by the fact that some of them are included in the price of the goods, without being a structural part of the production costs (indirect taxes), while the rest are charged to profit or are a part of the costs of the enterprise.

A variety of tax incentives for innovation have been introduced, for example, in order to support innovation, income tax payers have the right to reduce taxable income depending on the amount of funds allocated to modernization, to the technical and technological renewal of equipment, the purchase of new equipment, the repayment of loans for these purposes, the reimbursement of the cost of lease assets, for five years but not more than $30 \%$ of taxable income. When calculating tax on the property of legal entities, there is a reduction of the tax base on the value of newly commissioned equipment for a period of five years (Republic of Uzbekistan, 2007).

A significant aspect of public support for innovation is the Decree of the President of the Republic of Uzbekistan, dated on July 15, 2008, on additional measures to stimulate innovative projects and technologies in production. It states that the funds allocated to finance modernization and new technologies that are used by business entities for funding applied scientific research and for the development of innovative projects, for development projects and their implementation, for training and research institutions and organizations and also for design organizations were exempted on the 1st of January 2013 from the payment of income tax, single tax, VAT and mandatory payments to the state trust funds (except single social tax), in so far as applied research 
and development work contracted with business entities; equipment imported for the re-equipping and retrofitting of research institutions and organizations, as part of the modernization included in the lists approved by the Cabinet of Ministers of Uzbekistan, is exempt from customs duties (excluding charges for customs clearance) (Karimov, 2008; Tillyakhodjaev, 2010).

Also, support for small and medium-size enterprise development in the sphere of innovation lies in the Resolution of the Cabinet of Ministers of Uzbekistan No. 144, "on additional measures to stimulate innovative projects in production", which provides:

(1) grants, including those from the fund for entrepreneurship support and those for the reconstruction of enterprises from the State Committee and the Chamber of Commerce;

(2) assistance with the establishment of modernization and new technologies, the sources of which are part of depreciation and net profit businesses (Karimov, 2008).

As a result of this legislation and normative, the number of companies developing innovations in science and technology is 156 . However, the Republic of Uzbekistan allowed accelerated depreciation in order to tax deductions, thus restricting the standards established by the tax code. This means that, in determining the tax base, depreciation deductions are deductible only to a certain limit and the difference from exceeding those standards, which arose in the calculation of the accelerated depreciation method, is included in the tax base for income tax. Moreover, the taxpayer is not entitled to deduct the difference from the tax base, even in subsequent years. As a result, for companies in Uzbekistan there is no effect from the use of accelerated depreciation for income tax.

In such circumstance, it is important to mention that favorable conditions for increasing the flow of investment in the real sector of the economy will come about with the proper development of specific schemes that bring about the possibility of faster and more efficient returns on investments in fixed assets.

Thus, depreciation has a direct effect on the tax base for corporate profit tax. Additionally, depreciation policy determines the residual cost of assets, which is the tax base of property tax. Hence, an increase in depreciation charges reduces the tax base of property and income tax and can potentially act as a stimulus for investments (Arkin et al., 2003). Acute interest in the depreciation mechanism may also be attributed to the fact that depreciation charges are, at present, an important source of capital budgeting for enterprises in the Uzbek economy.

The present study focuses on the modeling of the mechanism of accelerated depreciation that is aimed at attracting investments to BPA for the real Uzbek sector. Such models should include a certain number of factors.

\section{Literature Review}

There are many publications devoted to the stimulation of investment using fiscal methods. For this reason, this article will focus entirely on studies that are directly associated to the topic of the article. Particularly, this article will not refer to papers that study the influence of aggregated tax incentives on macroeconomic variables of investment activity (a detailed empirical analysis of the efficiency of the aggregated sub-federal tax incentives for the attraction of investments was carried out in the EERC framework by Evgeniya (2000)) or to regional tax competition to draw in investments (a survey of this subject is found, for instance, a research in Inman and Rubinfeld (1996)). Studies that deal with the influence of tax exemptions on a firm's activity are much closer to the question of this article, although in general, they consider an already established firm. To this respect, Aukutsionek and Batyaeva (2001) conducted a study into the influence of taxation on the financial 
and economic state of an enterprise. Their study is based on monitoring data from Russian enterprises within the Russian Economic Barometer program. A considerable number of papers deal with the problem of choice of depreciation policy and its influence on the activity of enterprises. Although accounting documents define strict rules for depreciation policies, in many cases, there is still a certain degree of freedom in the choice of both the rate and method of depreciation. The minimization of present tax payment values by choosing a particular depreciation policy has also been studied (Roemmich, Duke, \& Gates, 1978; Berg \& Moore, 2001). This alternative could also suffer considerably from the random nature of future cash flows. To this respect, there are remarkable papers by Arkin et al. (2003), in which this value of future tax payments of the firm (within the progressive tax scale) is compared using two methods of depreciation, straight-line (in equal elements), and "accelerated" (in non-equal parts, decreasing in time). Although the "accelerated depreciation" may appear to be presumably the most favorable (due to a discount effect), the ideal choice of depreciation method in reality might depend on the degree of uncertainty of cash flow, discount rate, fiscal regulations, and the possibility of transferring the losses to other periods of time. Wakeman (1980) has shown that if the tax rate is flat and if taxable income is non-negative in all periods for all available depreciation methods, the accelerated depreciation method is most preferable for tax purposes. With reference to the Russian system of profit taxation, the investment waiting model, which is a development of the McDonald-Siegel model, was proposed by Arkin and Slastnikov (2007). The extension of this model by the introduction of a lag period between the moment of investment and production was studied by Arkin and Slastnikov (2007).

\section{Methodology}

In the accelerated depreciation mechanism model, the current tax rates (see Table 1) in the Republic of Uzbekistan were used. Any methodology should take into account the interests of both the State and the economic entity and to create this method, the following was taken into account:

(1) factors that may influence the formation, such as a depreciation fund, and the amount of payments of income tax and property tax, such as: initial (residual) value fixed assets, net sales, costs, sum of depreciation charges, tax base for property tax, tax base for income tax, income tax rate, and property tax rate.

(2) indicators, which are influenced by changing size, to establish the rate of income tax and property tax:

- Income tax: an indicator with a direct relationship to the basic production assets revenue growth due to the increase in labor productivity. Such an indicator can be:

$$
\text { Fixed Asset Turnover }\left(F_{0}\right)=\frac{\text { Net sales }}{\text { Average net fixed assets }}
$$

This indicator reflects the effectiveness of only using the organization's basic production assets. Therefore, it grows faster than the numerator compared to the denominator, and per unit of fixed production assets has more units of revenue. This is only possible due to the continuous updating of the basic production assets of high-tech, modern, and more efficient equipment.

- Property tax: an indicator, which may reflect the quarterly or annual process of increasing or reducing the residual value of fixed assets at the end of each reporting period. Such an indicator can be:

$$
\text { Increase BPA }=\frac{\text { BPA at the end of period }}{\text { BPA at the beginning of year }}
$$

This indicator reflects the change in the value of the cost of fixed production assets for the period. Thus, if at the end of the reporting period, the value of the residual value of fixed assets is more than at the beginning of 
the period, this will be the basis to encourage the state to reduce property taxes in proportion to the amount by which the company acquired assets. If this index is equal to or greater than one, it is a positive factor for the enterprise. This means that at the end of the reporting period in which property, plant, and production equipment were acquired, the cost at least covers the amount of accumulated depreciation for the period.

Two of the real and effective factors that will stimulate the economic entity to constantly update BPA are:

(1) a reduction of the income tax rate with an increasing index Fixed Asset Turnover $\left(F_{0}\right)$ which means that each state can set its own reduction bands. If $F_{0}$ is equal to one unit, then the basic rate of tax on profits $\alpha$ $9 \%$ (0.09), incrementing $F_{0}$ by 0.05 points ( $5 \%$ ) will mean a reduction in the $\alpha$ by 0.005 points $(0.5 \%)$. So, by increasing $F_{0}$ by five times ( 0.25 points), and $F_{0}=1.25$ units, $\alpha$ will decrease by 0.025 points $(2.5 \%)$, and make up $21.5 \%(0.215)$. Data manipulation with the rate of income tax will spur the economic entity to always support their high-tech equipment. This will bring about the opportunity, first of all, to increase revenues $V$ and secondly, to increase the depreciation fund to such an extent that it will give the optimal residual value $R_{t}$ and as a result, to pay tax on profit $T_{i}$ at discounted rates. If income tax is paid by enterprises on a quarterly basis (annually), the calculation of the return on assets is done at the end of each quarter (of the year), and on the basis of the obtained values will clear the income tax rate.

(2) a reduction of the property tax rate by increasing the residual value of the BPA, so each state can set its own size reduction bands. If the change $\triangle \mathrm{BPA}$ is less than one unit, then the basic property tax rate $\gamma$ is $2.2 \%$ (0.022). Increments of $\triangle \mathrm{BPA}$ by 0.01 points will mean a reduction in the $\gamma$ by $0.0001(0.1 \%)$. Thus, by increasing $\triangle \mathrm{BPA}$ by 10 times $(0.1$ point), increase $\mathrm{BPA}=0.1$ to $1(10 \%), \gamma$ will decrease by $0.001(0.1 \%)$, and make up $2.1 \%$ (0.021). Data manipulation with the rate of property tax will encourage the entity to constantly maintain the residual value of BPA at an optimal level, which will make it possible to pay property tax at reduced rates. If companies pay the amount of property tax $L_{t}$ quarterly (annual), the calculation of $\triangle \mathrm{BPA}$ will be at the end of each quarter (of the year), and on the basis of the obtained values will clear the property tax rate.

\section{Variance Sum Calculation of Income Tax}

Calculating $F_{0}$ values for the calculation of the income tax rate is:

$$
\begin{gathered}
F_{\mathrm{o}}=\frac{V_{t}}{R_{t}} \leq 1 \alpha(9 \%) \\
F_{\mathrm{o}}=\frac{V_{t}}{R_{t}} \geq 1 \alpha(\text { less than } 9 \%)
\end{gathered}
$$

Computation of the amount of income tax $T_{t}$ is:

$$
T_{t}=D_{t} \alpha
$$

Profit calculation before taxation $D_{t}$ is:

$$
D_{t}=V_{t} S_{t}
$$

Cost calculation $S_{t}$ is:

$$
S_{t}=Z_{t}+A_{t}
$$

where means $Z t$ total expenses (excluding depreciation) for produced goods.

The calculation of depreciation $A_{t}$ is as follows:

$$
\begin{gathered}
A_{t}=R_{t} \beta A_{f} \\
T_{i_{t}}=\left(V_{t}-\left(Z_{t}+A_{t}\right)\right) \alpha
\end{gathered}
$$

Supposing that $Z_{t}$ consists only of the sum of depreciation charges, then: 


$$
T_{i_{t}}=\left(V_{t}-A_{t}\right) \alpha
$$

\section{Variation Sum Calculation of Property Tax}

Calculation of the "Gain BPA" for the value of the property tax rate is:

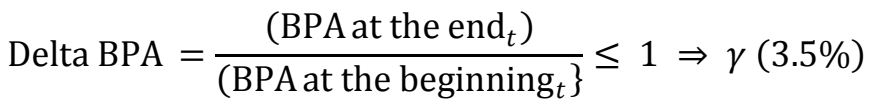

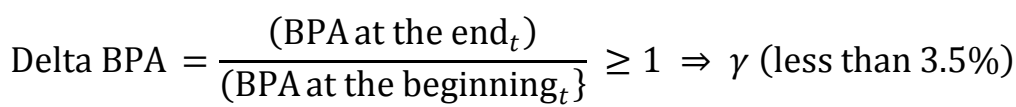

The calculation of the average annual value of taxable property is:

$$
A V_{p}=\frac{N V_{0}+N V_{m}+N V_{r}}{\text { Number of months in the rep.year (tax })+1}
$$

where the average annual value of the property for the reporting (tax period) $=A V_{P}$; net book value of assets at the beginning of the year $=N V_{y}$; net book value of assets at the beginning of each month in the reporting period $=N V_{m}$; net book value of assets at the beginning of the month following the reporting $(\operatorname{tax})$ period $)=$ $N V_{r}$.

When $\mathrm{t}=$ quarter,

$$
\begin{aligned}
& \overline{R_{t}}=\frac{\left(R_{b_{t}}+R_{1}+\cdots+R_{3}+R_{e_{t}}\right)}{3+1} \\
& \overline{R_{t}}=\frac{\left(R_{b_{t}}+R_{1}+\cdots+R_{3}+R_{e_{t}}\right)}{12+1}
\end{aligned}
$$

The calculation of the amount of tax that must be paid to the budget by the end of the reporting period (quarter, six month, year): $L_{t}=\frac{A V_{p}}{4} \gamma$,

$$
\begin{gathered}
L_{t}=R_{t} \frac{\gamma}{4} \\
\text { Net result of year } L_{t}=R_{t} \gamma
\end{gathered}
$$

\section{Mathematical Model}

To study the formation of the laws of the process and also the output of the formulas, the mathematical model has been constructed in this article.

Derivation of the formula for the calculation of the variation of income tax. During the first year of operation, the value of the residual value of fixed assets will be equal to their original value, as:

$$
R_{\mathrm{o}}=I
$$

In the second year $t=1$, the residual value will be equal to the original cost less depreciation as calculated based on $A_{f}$,

$$
R_{1}=I-I \beta A_{f}=I\left(1-\beta A_{f}\right)
$$

Thus the sum of variation income tax in the first year amounts to

$$
T_{i}=\left(V_{1}-\beta A_{f} R_{1}\right) \alpha
$$

$$
\text { When } t=2, R_{2}=I\left(1-\beta A_{f}\right)-I\left(1-\beta A_{f}\right) \beta A_{f} \text { or } R_{2}=I\left(1-\beta A_{f}\right)^{2}
$$

The pattern of formation of the residual value in a particular period $t$ is obvious. Summarizing equations (4), (5), and (7), generally received is:

$$
R_{t}=I\left(1-\beta A_{f}\right)^{t}, t=\overline{0, \Omega-1}
$$

Thus the sum of variations in income tax in a randomly selected year amounts to 


$$
T_{i_{t}}=\left(V_{t}-\left(\beta A_{f} R_{t}+L_{t}\right)\right) \alpha
$$

The total amount of deferred income tax during time $\Omega$ can be calculated by adding index $t$ to equation (10):

$$
T_{i}=\sum_{t=0}^{\Omega-1} T_{i_{t}}
$$

Derivation of the formula for the calculation of variations of property tax. The calculation of the average annual value of BPA in the quarter, taking into account equations (1) and (2), is as follows:

$$
L_{t}=\frac{\frac{R_{b_{t}}+R_{1}+\cdots+R_{12}+R_{e}}{12+1} \gamma}{4}
$$

The calculation of the average annual value of BPA in their first year, taking into account equations (1) and (3), is as follows:

$$
L_{-} t=\frac{\frac{R_{b_{t}}+R_{1}+\cdots+R_{12}+R_{e}}{4} \gamma}{12+1}
$$

Thus, the final equation that calculates the amount of variation of income tax and property tax, taking into account equations (9) and (12) will be as follows:

$$
T_{i_{t}}=\left(V_{t}-\left(\beta A_{f} R_{t}+\frac{R_{b_{t}}+R_{1}+\cdots+R_{12}+R_{e_{t}}}{12+1} \gamma\right)\right) \alpha
$$

\section{Examples According to This Method}

Below there is a calculation in which there is no variation in the use of the tax system of tax accounting rules.

Using the straight-line method to calculate the charge of depreciation. The cost of BPA is equal to USD 100,000. The useful life is 10 years. Table 2 is obtained.

Table 2

The Straight-line Method to Calculate the Charge of Depreciation

\begin{tabular}{llll}
\hline Year & Residual value at beginning of year & Accrued annual depreciation & Residual value at beginning of year \\
\hline 1 & 100,000 & 10,000 & 90,000 \\
2 & 90,000 & 10,000 & 80,000 \\
3 & 80,000 & 10,000 & 70,000 \\
4 & 70,000 & 10,000 & 60,000 \\
5 & 60,000 & 10,000 & 50,000 \\
6 & 50,000 & 10,000 & 40,000 \\
7 & 40,000 & 10,000 & 30,000 \\
8 & 30,000 & 10,000 & 20,000 \\
9 & 20,000 & 10,000 & 10,000 \\
10 & 10,000 & 10,000 & 0
\end{tabular}

Source: Compiled by author.

A property tax payment for the first year was made at a rate of $3.5 \%$ (Table 3 ).

The average annual value for one year is: $(100,000+90,000) \div 2=95,000$

Suppose revenue for the year was USD 100,000. From here,

$$
F_{0}=\frac{100,000}{95,000}=1.053
$$

Income tax rate is $9 \%$. The amount of income tax in the first year is:

$$
T_{t}=\left(V_{t}-\left(\beta A_{f} R_{t}+L_{t}\right)\right) \alpha=100,000-(10,000+3,325) \times 0.09=86,675 \times 0.09=7,801
$$


A payment of property tax for the last year was made at a rate of $3.5 \%$ (Table 4).

Income tax on profit for the last 10 years onwards is:

$$
T_{t}=\left(V_{t}-\left(\beta A_{f} R_{t}+L_{t}\right)\right) \alpha=(100,000-(10,000+110) \times 0.09=89,890 \times 0.09=8,090
$$

Table 3

Payment of Property Tax

\begin{tabular}{lcc}
\hline Month & Residual value & Sum of amortization \\
\hline 1 & $100,000.00$ & 833.33 \\
2 & $99,166.67$ & 833.33 \\
3 & $98,333.33$ & 833.33 \\
4 & 97,500 & 833.33 \\
5 & $96,666.67$ & 833.33 \\
6 & $95,833.33$ & 833.33 \\
7 & 95,000 & 833.33 \\
8 & $94,166.67$ & 833.33 \\
9 & $93,333.33$ & 833.33 \\
10 & 92,500 & 833.33 \\
11 & $91,666.67$ & 833.33 \\
12 & $90,833.33$ & 833.33 \\
13 & 90,000 & 833.33 \\
Value & $1,235,000$ & $10,833.33$ \\
Number of month 13 & & \\
Annual average value 95,000 & & \\
Tax rates 0.04 & & \\
Tax value 3,325 & & \\
\hline
\end{tabular}

Source: Compiled by author.

Table 4

Payment of Property Tax for the Last Year

\begin{tabular}{lcc}
\hline Month & Residual value & Sum of amortization \\
\hline 1 & $10,000.000$ & 833.33 \\
2 & $9,166.670$ & 833.33 \\
3 & $8,333.330$ & 833.33 \\
4 & $7,500.000$ & 833.33 \\
5 & $6,666.670$ & 833.33 \\
6 & $5,833.330$ & 833.33 \\
7 & $5,000.000$ & 833.33 \\
8 & $4,166.670$ & 833.33 \\
9 & $3,333.330$ & 833.33 \\
10 & $2,500.000$ & 833.33 \\
11 & $1,666.670$ & 833.33 \\
12 & 833.330 & 833.33 \\
13 & 0 & 0 \\
Value & 65.000 .00 & 10.000 .00 \\
Number of month 13 & & \\
Annual average value 5.000 .00 & & \\
Tax rates 0.022 & & \\
Tax value 110.00 & & \\
\hline
\end{tabular}

Source: Compiled by author. 
Further calculations using the rules of financial accounting. The cost of BPA is equal to USD 100,000, the useful life cycle is 10 years. Applying the declining balance method of $A_{\mathrm{f}}=1.5 \mathrm{in}$ Table 5, the depreciation is obtained.

A payment of property tax for the first year was made at a rate of $3.5 \%$ (Table 6).

Table 5

Declining Balance Method

\begin{tabular}{lccc}
\hline Year & Residual value at beginning of year. & Accrued annual depreciation & Residual value at beginning of year \\
\hline 1 & $100,000.00$ & $15,000.00$ & $85,000.00$ \\
2 & $85,000.00$ & $12,750.00$ & $72,250.00$ \\
3 & $72,250.00$ & $10,837.50$ & $61,412.50$ \\
4 & $61,412.50$ & $9,211.88$ & $52,200.63$ \\
5 & $52,200.63$ & $7,830.09$ & $44,370.53$ \\
6 & $44,370.53$ & $6,655.58$ & $37,714.95$ \\
7 & $37,714.95$ & $5,657.24$ & $32,057.71$ \\
8 & $32,057.71$ & $4,808.66$ & $27,249.05$ \\
9 & $27,249.05$ & $4,087.36$ & $23,161.69$ \\
10 & $23,161.69$ & $23,161.69$ & 0.00 \\
\hline
\end{tabular}

Source: Compiled by author.

Table 6

Calculation of Property

\begin{tabular}{lrc}
\hline Month & Residual value & Sum of Amortiztion \\
\hline 1 & $100,00.00$ & $1,250.00$ \\
2 & $98,750.00$ & $1,250.00$ \\
3 & $97,500.00$ & $1,250.00$ \\
4 & $96,250.00$ & $1,250.00$ \\
5 & $95,000.00$ & $1,250.00$ \\
6 & $93,750.00$ & $1,250.00$ \\
7 & $92,500.00$ & $1,250.00$ \\
8 & $91,250.00$ & $1,250.00$ \\
9 & $90,000.00$ & $1,250.00$ \\
10 & $88,750.00$ & $1,250.00$ \\
11 & $87,500.00$ & $1,250.00$ \\
12 & $86,250.00$ & $1,250.00$ \\
13 & $85,000.00$ & $1,062.50$ \\
Value & $1,202,500.00$ & $16,062.50$ \\
Number of Month 13 & & \\
Annual Average Value 92,500.00 & & \\
Tax rates 0.035 & & \\
Tax value 3.237,50 & & \\
\hline
\end{tabular}

Source: Compiled by author.

The average annual value for 1 year is $(100,000+85,000) \div 2=92,500$

Suppose revenue for the year was equal to USD 100,000, then from here,

$$
F_{\mathrm{o}}=\frac{100,000}{92,500}=1.081
$$


The income tax rate is $9 \%$. The amount of income tax in the first year is:

$$
T_{t}=\left(V_{t}-\left(\beta A_{f} R_{t}+L_{t}\right)\right) \alpha=(100,000-(15,000+3,237) \times 0.09=81,732 \times 0.09=7,359
$$

With the use of different methods of calculating depreciation for tax and financial accounting, without inserting money in places, without an increase in BPA and the absence of variation in tax rates, the amount of tax lost by the state is USD 442.13 .

Further calculations using the rules of variation. The cost of BPA is equal to USD 100,000. The useful life is 10 years. Applying to the declining balance method when $A_{f}=1.5$, the depreciation is obtained in Table 5 . The net amount of depreciation is equal to USD 15,000 which reduces the amount of income tax by USD 1,350. This amount is available to obtain new high-tech BPA. If, for one USD value of the existing BPA, equally the enterprise received one USD of revenue, then, with a new one USD value of BPA, the revenue is equal to two USD.

$$
\text { Revenue }=100,000+(1,350 \times 2)=102,700
$$

Annual average value for one year is:

$$
\frac{100,000+85,000+1,350}{2}=93,175 ; F_{\mathrm{o}}=\frac{102,700}{93,175}=1.102
$$

Here, it is possible to see from baseline $F_{0}$ that there was an increase, as a result of that the income tax rate will decrease by $7.9 \%$. At the end of the reporting period, the amount of income tax will be calculated at the rate of $7.9 \%$.

A payment of property tax for the first year was made at a rate of $3.5 \%$ (Table 6):

$$
(\text { Increase BPA })=\frac{\text { BPA at the end of period }}{\text { BPA at the beginning of year }}=\frac{85,000+1,350}{100,000}=0.864
$$

As 0.864 is less than the base rate of one unit, the company cannot pay this tax at a reduced rate. If the state base rate was 0.8 , then the entity would be able to pay at a reduced rate, moreover, the sum of income tax in the first year amounts to:

$$
T_{i_{t}}=\left(V_{t}-\left(\beta A_{f} R_{t}+L_{t}\right)\right) \alpha=(102,700-(15,000+3,238)) \times 7.9 \%=6,565.89
$$

Comparing the second method of calculating taxes with the third method which has been described in Table 7, the difference is relatively small. When the entity invests money it has saved, for the process of convergence, the amount of taxes with the first and third method of calculating taxes are obvious. Based on the above calculations, the following pattern was revealed: Larger investment tax funds released in the BPA, increase tax revenues by initially reducing tax bases. To confirm this pattern the following example will be checked.

Table 7

The Comparison Table

\begin{tabular}{lll}
\hline View & Sum of income tax & Sum of property tax \\
\hline 1. Straight-line method of depreciation & $7,800.75$ & $3,325.00$ \\
2. Method of declining balance & $7,358.63$ & $3,237.50$ \\
3. Method of declining balance using varying tax rates & $6,565.89$ & $3,237.50$ \\
\hline
\end{tabular}

Source: Compiled by author. 
Further calculations using the rules of financial accounting. The cost of the BPA is USD 100,000. The useful life cycle is equal to 10 years. Applying the declining balance method of $A_{f}=4$, then the depreciation is obtained in Table 8.

Table 8

Residual Value and Annual Depreciation

\begin{tabular}{lccc}
\hline Year & Residual value at beginning of year & Accrued annual depreciation & Residual value at beginning of year \\
\hline 1 & $100,000.00$ & $40,000.00$ & $60,000.00$ \\
2 & $60,000.00$ & $24,000.00$ & $36,000.00$ \\
3 & $36,000.00$ & $14,400.00$ & $21,600.00$ \\
4 & $21,600.00$ & $8,640.00$ & $12,960.00$ \\
5 & $12,960.00$ & $5,184.00$ & $7,776.00$ \\
6 & $7,776.00$ & $3,110.40$ & $4,665.60$ \\
7 & $4,665.60$ & $1,866.24$ & $2,799.36$ \\
8 & $2,799.36$ & $1,119.74$ & $1,679.62$ \\
9 & $1,679.62$ & 671.85 & $1,007.77$ \\
10 & $1,007.77$ & $1,007.77$ & 0.00 \\
\hline
\end{tabular}

Source: Compiled by author.

The result of a depreciation amount equal to USD 40,000 reduces the amount of income tax by USD 3,600. This amount is available to obtain new high-tech BPA. If, for one USD value of the existing BPA, equally the enterprise received one USD of revenue, then, with a new one USD value of BPA, the revenue is equal to two USD.

$$
\text { Revenue }=100,000+(3,600 \times 2)=107,200
$$

Annual average value for 1 year: $\frac{100,000+60,000+3,600}{2}=81,800 ; F_{0}=\frac{107,200}{81,800}=1.311$

From baseline of $F_{0}$, it can be seen that there was an increase, as a result of that the income tax rate will decrease by $3.11 \%$ and be equal to $7.69 \%$. At the end of the reporting period, the amount of income tax will be calculated at the rate of $7.69 \%$. A payment of property tax for the first year was made at a rate of $3.5 \%$ (Table 9)

$$
T_{i_{t}}=\left(V_{t}-\left(\beta A_{f} R_{t}+L_{t}\right)\right) \alpha=(107,200-(40,000+2,800)) \times 7.69 \%=64,400 \times 7.69=4,952
$$

An analytical calculation of the amounts of income tax and property tax in the last year was performed, as it was done in example 1.

A payment of property tax for the last year was made at a rate of $3.5 \%$ (Table 10).

With the amount of income tax in the last 10 years onwards (respectively at a rate of $94 \%$ ) based on the calculation $F_{0}$, it can be got:

$$
T_{i_{t}}=\left(V_{t}-\left(\beta A_{f} R_{t}+L_{t}\right)\right) \alpha=(107,200-(1,007.77+17.64)) \times 9 \%=106,174 \times 9 \%=9,556
$$

As it can be seen, there is a difference between the income tax expense from USD 8,090 in 10 years in example 1 and the sum of USD 9,556 respectively. Whereas, the state in any circumstance can gain benefit in the form of increased tax revenue. 
Table 9

Payment of Property Tax

\begin{tabular}{lrc}
\hline Month & Residual value & Sum of amortization \\
\hline 1 & $100,000.00$ & $3,333.33$ \\
2 & $96,666.67$ & $3,333.33$ \\
3 & $93,333.33$ & $3,333.33$ \\
4 & $90,000.00$ & $3,333.33$ \\
5 & $86,666.67$ & $3,333.33$ \\
6 & $83,333.33$ & $3,333.33$ \\
7 & $80,000.00$ & $3,333.33$ \\
8 & $76,666.67$ & $3,333.33$ \\
9 & $73,333.33$ & $3,333.33$ \\
10 & $70,000.00$ & $3,333.33$ \\
11 & $66,666.67$ & $3,333.33$ \\
12 & $63,333.33$ & $3,333.33$ \\
13 & $60,000.00$ & $2,000.00$ \\
Value & $1,040,000.00$ & $42,000.00$ \\
Number of Months 13 & & \\
Annual Average Value 80,000.00 & & \\
Tax rates 0.035 & & \\
Tax value 2,800.00 & & \\
\hline
\end{tabular}

Table 10

Payment of Property Tax for the Last Year

\begin{tabular}{lrc}
\hline Month & Residual value & Sum of Amortization \\
\hline 1 & $1,007.77$ & 83.98 \\
2 & 923.79 & 83.98 \\
3 & 839.81 & 83.98 \\
4 & 755.83 & 83.98 \\
5 & 671.85 & 83.98 \\
6 & 587.87 & 83.98 \\
7 & 503.88 & 83.98 \\
8 & 419.90 & 83.98 \\
9 & 335.92 & 83.98 \\
10 & 251.94 & 83.98 \\
11 & 167.96 & 83.98 \\
12 & 83.98 & 83.98 \\
13 & 0.00 & 0.00 \\
Value & $6,550.50$ & $1,007.77$ \\
Number of months 13 & & \\
Annual average value 503.88 & & \\
Tax rates 0.035 & & \\
Tax value 17.64 & & \\
\hline
\end{tabular}

Source: Compiled by author.

\section{Conclusions}

In terms of economic policy, when there is quite a limited possibility of increasing investment in the means of production, capital efficiency depends not only on the fulfillment of the entity's technological structure, but also on the use of rational methods of financing the cost of the equipment. In this situation, the 
use of a depreciation fund, as a method of financing, consistent with the principles of the intensive expanded reproduction of capital assets, would be an effective tool for the renovation of fixed assets.

The optimal choice of management strategy for residual value and depreciation fund BPA is the prerogative of the entity carrying out this action, based on the structure of the tax policy of the state's variation in tax rates. The entity, using the formulas given above can answer the question of at which point in time $(t)$ or at which time interval the residual value of BPA will be optimal for the entity, based on tax rates.

Summarizing all the above, it is possible to say that in theory it is reasonable to permit a company to create and distribute a depreciation fund, depending on the market situation. It can be produced at the expense of taxes, thus encouraging the entity to constantly channel funds to upgrade BPA.

In almost all developed countries, the government is the initiator and direct participant in stimulating and supporting innovation in enterprises. At the same time, tax mechanisms to support innovation occupy an especially significant role that should be strengthened and developed.

In the Republic of Uzbekistan, encouraging the tax policy in this article and also putting into practice the experience of most developed countries would result in financial support for R\&D with the proper development of specific schemes that would bring about the possibility of a faster and more efficient return investment in fixed assets in the economy, which in turn would create favorable conditions for increasing the flow of investments in the real sector of the economy.

\section{References}

Arkin, V. I., \& Slastnikov, A. D. (2007). The effect of depreciation allowances on the timing of investment and government tax revenue. Annals of Operations Research, 151(1), 307-323.

Arkin, V. I., Slastnikov, A. D., \& Arkina, S. (2003). Investment stimulation by a depreciation mechanism (No. 02-05e, EERC Research Network, Russia and CIS).

Aukutsionek, S., \& Batyaeva, A. (2001). What tax reforms are profitable for the State? Voprosy economiki. Retrieved from http://econpapers.repec.org/article/nosvoprec/2001-09-0788.htm

Berg, M., \& Moore, G. (1989). The choice of depreciation method under uncertainty. Decision Sciences, 20(4), 643-654.

Evgeniya, K. (2000). Sub-federal tax exemptions in Russia: Less taxes, more investment? EERC Research Network. Retrieved from http://EconPapers.repec.org/RePEc:eer:wpalle:2k/07e

Filip, P. (2012). Supporting small and medium sized enterprises in the background available sources of financing (Zborník vedeckých prác katedry ekonómie a ekonomiky ANNO2012, pp. 56-67, Rastislav Kotulič).

Hall, B. H. (2005). The financing of innovation. In S. Shane (Ed.), Blackwell handbook of technology and innovation management. Oxford: Blackwell.

Inman, R. P., \& Rubinfeld, D. L. (1996). Designing tax policy in federalist economies: An overview. Journal of Public Economics, 60(3), 307-334.

Joppe, A., Sproge, I., \& Zelgalvis, E. (2010). Role of taxes in the promotion of innovative activity. Retrieved from http://www.ism.lt/bmra/2010/ CP\%2080\%20Zelgalvis-Joppe-Sproge.pdf

Karimov, I. A. (2008). ДокладПрезидентаРеспубликиУзбекистанИ.А. Каримов, 2008, Одополнительныхмерахпостимулированиювнедренияинновационныхпроектовитехнологийвпроизводство (Report of the President of the Republic of Uzbekistan Islam Karimov, 2008 on additional measures to stimulate innovative projects and technologies in production). Retrieved from http://narodnoeslovo.uz/index.php?Option=com_content \&view $=$ article $\&$ id $=405:$ doklad $\&$ catid $=14:$ oficial $\&$ Itemid $=12$

Karimov, I. А. (2013). Президента Республики Узбекистан Ислама Каримова на заседании Кабинета Министров, посвященном основным итогам 2012 года и приоритетам социально-экономического развития на 2013 год (Report of the President of Uzbekistan Islam Karimov at the meeting of the Cabinet of Ministers on the main results of 2012 and the priorities of socio-economic development in 2013). Retrieved from http://www.pressservice.uz/ru /news/show/dokladi/doklad_prezidenta_respubliki_uzbekist_1/ 
Kurczodyna, J. E. (2010). Method and system for implementing a fast amortization schedule index mortgage fund. Retrieved from https://www.google.je/patents/US20100293091?dq=Method+and+system+for+implementing+a+fast+amortization+schedule +index+mortgage+fund

Lobont, O., Moldovan, N., \& Corduneanu, C. (2010). Financial instruments designed to increase the competiveness of the European firms. Euro Economica, 3(26), 51-59.

Republic of Uzbekistan. (2007). НАЛОГОВЫЙ КОДЕКС РЕСПУБЛИКИ УЗБЕКИСТАН (Tax code of the Republic of Uzbekistan). Retrieved from http://www.lex.uz/Pages/Get Act.aspx?lact_id=1286689

Republic

of

Uzbekistan.

(2009).

ОпрогнозеосновныхмакроэкономическихпоказателейипараметрахгосударственногобюджетаРеспубликиУзбекистанн a 2011 год (On the forecast of key macroeconomic indicators and parameters of the state budget of the Republic of Uzbekistan for 2011).

Roemmich, R., Duke, G. L., \& Gates, W. H. (1978). Maximizing the present value of tax savings from depreciation. Management Accounting, 56, 55-57.

Shatalova, O. (2012). On arrangement and some results of statistic observations of innovative activities in the Russian federation. Ekonomika Management Inovace, 9, 71-81.

Stradi, B., \& Haven, M. (2005). Optimal investment strategy via interval arithmetic. International Journal of Theoretical and Applied Finance, 8(2), 185-206.

Tillyakhodjaev, M. (2010). Strengthening of innovation activity at the cotton ginning industry in Uzbekistan. Perspectives of Innovations, Economics and Business, PIEB, 1(4), 52-53.

Wakeman, L. M. (1980). Optimal tax depreciation. Journal of Accounting and Economics, 2(3), 213-237. 